\title{
Sınıf Öğretmenleri ve Sınıf Öğretmeni Adaylarının Bilimin Doğasına İlişkin Görüşleri
}

\author{
Views of the Elementary Teachers and Pre-Service Elementary Teachers on the \\ Nature of Science
}

\section{Esra SARAÇ* Evren CAPPELLARO**}

Öz: Bu çalışmanın amacı, sınıf öğretmenlerinin ve sınıf öğretmeni adaylarının bilimin doğası hakkındaki görüşlerini ortaya çıkarmaktır. Araştırmanın çalışma grubunu 116 sınıf öğretmeni ve 105 sınıf öğretmeni adayı oluşturmuştur. Katılımcıların görüşlerini belirlemek amacı ile Doğan (2005) tarafından Türkçeye çevrilmiş ve adapte edilmiş olan 25 maddelik VOSTS-TR anketi kullanılmıştır. Anket ile elde edilen verileri derinleştirmek amacıyla 10 sınıf öğretmeni ve 8 öğretmen adayı ile yarı yapılandırılmış görüşmeler yapılmıştır. Araştırmada elde edilen veriler analiz edildiğinde katılımcıların; toplumun bilim üzerine etkisi, bilimin toplum üzerine etkisi, gözlemlerin doğası, sınıflama düzeninin doğası, bilimsel bilginin geçiciliği ve değişebilirliği hakkında gerçekçi görüşlere sahip oldukları görülürken, bilimsel buluşlarla cinsiyetin ilişkisi, bilimsel modellerin doğası, hipotez-teori-kanun arasındaki ilişki ve bilimsel bilginin epistemolojik durumu hakkında yetersiz görüşlere sahip oldukları görülmüştür. Katılımcılarla yapılan görüşmeler bu sonuçları desteklemiştir. Öğretmen ve öğretmen adaylarının bilimin doğası ile ilgili görüşlerinde; hipotez-teori-kanun hiyerarşisi ile bilimler arası kavramların tutarlılığı konuları dışında anlamlı bir farklılık olmadığı tespit edilmiştir.

Anahtar sözcükler: Bilimin Doğası, Sınıf Öğretmenleri, Sınıf Öğretmeni Adayları, Fen Eğitimi

\begin{abstract}
The aim of this study is to reveal the views of the elementary teachers and pre-service elementary teachers on the nature of science. The study group of the research has consisted of 116 teachers and 105 pre-service teachers. The questionnaire of VOSTS-TR adapted to Turkish by Doğan (2005) was used with the aim of determining the views of the participants. Half-structural interviews were made with 10 teachers and 8 pre-service teachers with the aim of detailing the data obtained by the questionnaire. Evaluations of the collected data revealed that the participants had realistic views on the effect of society on science, the effect of the science on society, the nature of observations, nature of the classification scheme, impermanence and variability of scientific knowledge; while they had insufficient views on the relation between gender and scientific inventions, the nature of scientific models, the relation between hypothesis-theory-law and epistemological status of scientific knowledge. The interviews made with the participants supported these results. It was determined that there is no significant difference in their views on the nature of science, apart from two topics related to hypothesistheory-law hierarchy and the consistency of interdisciplinary concepts.
\end{abstract}

Keywords: Nature of Science, Teachers, Pre-Service Teachers, Science Education

\footnotetext{
* Ögr. Gör., Kilis 7 Aralık Üniversitesi, Eğitim Fakültesi, İlköğretim Bölümü Sınıf Eğitimi ABD, Kilis. sarac.esra@hotmail.com

** Ögr. Gör. Dr., Akdeniz Üniversitesi, Eğitim Fakültesi, İlköğretim Bölümü Sınıf Eğitimi ABD, Antalya. evrenne@gmail.com
} 
Günümüz dünyasında her geçen gün yeni bilimsel ve teknolojik gelişmeler olmakta, yeni bilgiler ortaya çıkmaktadır. Toplumdaki bireyler üretilen bilimsel bilgiyi ve teknolojiyi doğru şekilde anlayıp bunlardan doğru şekilde faydalandıkları zaman, içinde yaşadıkları toplumun yaşam standartlarını da yükseltmiş olurlar. Bilimde ve bilimsel bilgide meydana gelen bu değişimlerin takip edilebilmesi için ise her şeyden önce bilimsel düşünme biçiminin toplumların bireyleri tarafından anlaşılması gerekmektedir. Bu amaca ulaşmada en önemli araçlardan birisi de eğitim sistemidir (Doğan-Bora, Arslan \& Çakıroğlu 2006). Bir bireyin bilimsel bilgi ile planlı ve belli bir program çerçevesinde ilk karşılaşması okulda olmaktadır (Derman 2014). Okullarda verilen fen eğitimi öğrencilerin bilimsel bilgi farkındalıklarını ve bilime bakış açılarını etkilemektedir (Lucas \& Roth 1996). Bilim ve bilimsel düşüncenin özellikleri konusunda farkındalık yaratmak, ilköğretim düzeyinden başlayarak her seviyede eğitimin başlıca amaçları arasındadır (AAAS 1990; NRC 1996; MEB 2013).

Bilimin doğasının öğrencilere öğretilmesi aynı zamanda onların bilimsel okuryazar olabilmeleri açısından da büyük önem taşımaktadır (AAAS 1990; Çepni 2011). Bilimin doğası bilimsel okuryazarlığın en önemli elemanı olarak görülebilir. Öğrencilerin bilimin doğasıyla ilgili farkındalıklar geliştirmesi fen eğitiminin temel amaçları arasında yer almaktadır (MEB 2013).

Bu noktadan hareketle, özellikle son yirmi yılda pek çok farklı ülkedeki uzmanlar ve bilim insanları bilimsel okuryazarlık ve bilimin doğasını anlama hedefini vurgulayan eğitim uygulamalarının gerekliliğine odaklanmışlardır (NRC 1996; Soloman, Scott \& Duveen 1996; Lederman 1999; Gess-Newsome 2002; Khishfe \& Abd-El Khalick 2002; Taber 2008; Posnanski 2010). Türkiye'de bu alandaki çalışmalara incelendiğinde ise öğretmen ve öğrencilerin bilimin doğası kavramlarına ilişkin görüşlerinin araştırıldığı çalışmaların sayısında son yıllarda büyük bir artışın olduğu gözlenmektedir (Macaroğlu, Baysal \& Şahin 1999; Çelik 2003; Taşar 2003; Morgil, Temel, Seyhan \& Alşan 2009; Aslan, Yalçın \& Taşar 2009; Çil 2010; Özcan 2013; Gül 2014; Deve 2015).

Öğrencilerin ve öğretmenlerin bilime ve bilimsel bilginin doğasına bakış açısını değerlendirmek üzere yurt dışında çok sayıda anket geliştirilmiştir. Bu araçlar, likert tipli, çoktan seçmeli ya da açık uçlu sorulardan oluşmaktadır (Lederman, Abd-El-Khalick, Bell \& Schwartz 2002). Türkiye'de ise araştırmacıların genellikle verileri toplamak için Aikenhead, Ryan ve Fleming (1989) tarafindan deneysel yolla geliştirilen, dokuz kategoriden ve 114 çoktan seçmeli sorudan oluşan "Fen'in Doğası Hakkındaki Görüşler" (VOSTS) anketi içinden maddeler seçilerek Türkçeye uyarlanan VOSTS-TR anketini kullandıkları görülmektedir (Doğan-Bora, Arslan \& Çakıroğlu 2006; Aslan, Yalçın \& Taşar 2009; Çetin 2009; Mihladız 2010; Aslan 2010; Doğan, Çakıroğlu, Çavuş, Bilican \& Arslan 2011; Mıhladız \& Doğan 2012; Aslan \& Taşar 2013; Çınar \& Köksal 2013; Ayvac1 \& Özbek 2015; Zorlu \& Baykara 2015).

Yurtdışında ve Türkiye'de yapılan çalışmaların sonuçları incelendiğinde eğitimin çeşitli kademesinde yer alan öğretmen ve öğrencilerin bilimin doğasına yönelik görüşlerinin yetersiz ya da yanlış olduğu görülmektedir (Solomon, Scott \& Duveen 1996; Palmquist \& Finley 1997; Abd-El Khalick \& BouJaoude 1997; Khishfe \& Abd-El Khalick 2002; Sadler 2004; Çelikdemir 2006; Küçük 2006; Liu \& Lederman 2007; Doğan \& Abd-El Khalick 2008; Buaraphan \& SungOng 2009; Afonso \& Gilbert 2010; Çil 2010; Doğan 2010). Bilimin doğasının öğrenciler tarafından tam anlaşılamamasının nedenleri arasında öğretmenlerin bilimin doğası hakkındaki görüşlerin yetersiz olması yer almaktadır (Lederman 1992). Çünkü bilimsel okuryazarlık ve bilimin doğası eğitimini veren öğretmenlerin görüşleri öğrencilerin görüşlerini de şekillendirmektedir (Pajares 1992; Water-Adams 2006). 
Bilimin doğası konusunda çalışmaların büyük bir bölümü ortaokul ve lise öğrencileri, fen bilgisi öğretmenleri ve öğretmen adayları üzerine oldukları görülmektedir. Oysaki öğrencilerin fen ile ilgili konularda fen bilgisi öğretmenlerinden önce sınıf öğretmenleri ile etkileşime girdikleri unutulmamalıdır. Etkili bir fen eğitiminin gerçekleştirilmesi için bilimsel düşünebilme, sorgulama, problem çözme yeteneği gibi üst düzey beceriler küçük yaşlardan itibaren öğrencilere kazandırılmalıdır (Muşlu 2008). Bu kazanımlara yönelik ilk çalışmalar ilkokul düzeyinde başlamakta olup sınıf öğretmenlerine önemli görevler düşmektedir. Bu bağlamda sınıf öğretmenlerinin bilimin doğası konusundaki görüşlerinin alınması ayrıca önemli görülmektedir. Fakat sınıf öğretmenleri ve öğretmen adaylarının görüşlerinin değerlendirildiği çalışmaların sayıs1 oldukça azdır (Murcia \& Schibeci 1999; Ar1 2010; Karakuyu \& Tüysüz 2011; Tatar, Yalçın \& Yalçın 2011). Türkiye'deki araştırmalar içerisinde ise sınıf öğretmenleri ve öğretmen adaylarının görüşlerinin karşılaştırıldığı bir çalışmaya ise rastlanmamıştır.

Yukarıda açıklanan nedenler düşünüldüğünde öğrencilerin bilim ve bilimsel olaylar ile ilgili olan konularla ilk olarak etkileşime geçtikleri sınıf öğretmenlerine çok büyük iş düşmektedir. Ayrıca tüm bu nedenlere bağlı olarak, hem sınıf öğretmeni adaylarının hem de görevlerini yapmakta olan sınıf öğretmenlerinin bilimin doğası hakkındaki görüşlerinin saptanması eğitim fakültelerindeki öğretmen yetiştirme programlarına ve sınıf öğretmenleri için hazırlanacak bilimin doğası temalı hizmet içi eğitimlere katkı sağlaması açısından oldukça önem taşımaktadır.

\section{Yöntem}

$\mathrm{Bu}$ çalışma, sınıf öğretmenleri ve sınıf öğretmeni adaylarının bilimin doğası hakkındaki görüşlerini betimlemeyi amaçlayan bir tarama çalışmasıdır.

\section{Araştırma Grubu}

Araştırmanın çalışma grubu, Akdeniz Üniversitesi Eğitim Fakültesi Sınıf Öğretmenliği Anabilim Dalı'nda öğrenim gören 105 öğretmen adayı ile Antalya ilindeki okullarda görev yapan 116 sınıf öğretmeni olmak üzere toplam 221 kişiden oluşmuştur.

\section{Veri Toplama Araçları}

$\mathrm{Bu}$ çalışmada nicel ve nitel araştırma yöntemleri bir arada kullanılarak anket ve yarı yapılandırılmış görüşme yolu ile toplanmıştır (Tablo 1). Türkiye'de bu alandaki araştırmalarda en çok tercih edilen veri toplama aracı anket olduğu için öğretmenlerin ve öğretmen adaylarının bilimin doğası ile ilgili görüşlerini belirlemek amacı ile Aikenhead, Ryan ve Fleming (1989) tarafından deneysel yolla geliştirilen, dokuz kategoriden ve 114 çoktan seçmeli sorudan oluşan 'Fen'in Doğası Hakkındaki Görüşler" (VOSTS) anketinin içinden Doğan tarafından 2005 yılında Türkçeye çevrilmiş ve adapte edilmiş olan 25 maddelik VOSTS-TR anketi kullanılmıştır. Öğretmen ve öğretmen adaylarının bilimin doğası ile ilgili görüş̧lerini daha derinlemesine ortaya koymak amacı ile 10 sınıf öğretmeni ve 8 öğretmen adayı ile yarı yapılandırılmış görüşmeler yapılmıştır. Görüşmeye katılanların gönüllü olmaları esas alınmıştır. Görüşmeler 15-20 dakika arasında sürmüş, ses kayıt cihazı ile kaydedilmiştir. Görüşme soruları, ankette yer alan sorulara paralellik sağlaması için anketteki; bilim, toplumun bilim ve teknoloji üzerine etkisi, bilim ve teknolojinin toplum üzerine etkisi, bilim insanının karakteristik özelliği, bilimsel bilginin sosyal yapısı, bilimsel bilginin karakteristik özellikleri kategorilerini yansıtacak şekilde alan uzmanlarının görüşü alınarak oluşturulmuştur. 
Tablo 1. VOSTS-TR Anketinde ve Görüşmede Yer Alan Soruların Dağılımı

\begin{tabular}{|l|l|l|}
\hline Kategoriler & VOST & Görüşme \\
\hline Bilim & 1 & 2 \\
\hline Toplumun bilim ve teknoloji üzerine etkisi & 2 & 1 \\
\hline Bilim ve teknolojinin toplum üzerine etkisi & 3 & 1 \\
\hline Bilim insanının karakteristik özelliği & 3 & 3 \\
\hline Bilimsel bilginin sosyal yapısı & 2 & 2 \\
\hline Bilimsel bilginin karakteristik özellikleri & 14 & 3 \\
\hline
\end{tabular}

\section{Verilerin Analizi}

Anketten elde edilen verilerin, betimsel istatistiği için anketteki maddelerin seçenekleri Rubba, Bradford ve Harkness'in (1996) kullandığ " "gerçekçi", "kabul edilebilir" ve "yetersiz" kategorileri olarak sınıflandırılmıştır. Bu gruplandırmaya göre; "yetersiz" kategorisi; uygun olmayan geleneksel bakış açısını, "kabul edilebilir" kategorisi; uygun (makul) olan bakış açısını, "gerçekçi" kategorisi ise çağdaş bakış açısını ifade etmektedir. Doğan (2005) tarafindan Türkçeye adapte edilen anketin seçeneklerinin sınıflandırılmasında da Doğan'ın bilim-teknoloji-toplum konularında ön bilgileri olan, fizik, kimya, biyoloji ile eğitim alanında uzman on bilim insanının görüşlerini alarak yaptığı sınıflandırma kullanılmıştır.

Bir tarama çalışması olan bu araştırmada anketler yoluyla elde edilen bilimin doğası hakkındaki öğretmen ve öğretmen adaylarının görüşlerinin farklılık gösterip göstermediğini analiz etmek amacıyla Ki-kare analiz testi kullanılmıştır.

\section{Bulgular}

Araştırmanın problemine ilişkin istatistiksel çözümlemelerle sınıf öğretmeni (Ö) ve öğretmen adaylarına (ÖA) uygulanan anket ve görüşmelerden elde edilen bulgular VOST-TR anketinde yer alan 9 kategori başlı̆g 1 altında aşağıda tablolar şeklinde sunulmuş ve yorumlanmıştır. Tablo 2 öğretmen ve öğretmen adaylarının bilimin tanımına olan bakış açılarını göstermektedir.

Tablo 2.Öğretmen ve Öğretmen Adaylarının Bilimin Tanımı Hakkındaki Görüşleri

\begin{tabular}{|c|c|c|c|c|c|c|c|c|}
\hline \multirow{2}{*}{ Madde } & \multicolumn{2}{|c|}{ Yetersiz } & \multicolumn{2}{|c|}{ Kabul Edilebilir } & \multicolumn{2}{|c|}{ Gerçekçi } & \multirow{2}{*}{$X^{2}$} & \multirow{2}{*}{ p } \\
\hline & ÖA\% & Ö\% & ÖA\% & $\ddot{O} \%$ & ÖA\% & Ö\% & & \\
\hline 1 & 2,1 & 4,5 & 69,1 & 78,6 & 28,9 & 17,0 & 4.802 & 4.802 \\
\hline
\end{tabular}

Bulgulara göre, öğretmen ve öğretmen adaylarının bilimin tanımı ile ilgili olan anketin 1. maddesi için kabul edilebilir bakış açısına sahip oldukları görülmektedir. Yapılan Ki-kare testinde bu madde için gruplar arasında anlamlı bir fark bulunamamıştır $\left(X^{2}=4.802 ; \mathrm{p}=.091\right)$.

Görüşmelerde ise katılımcılar bilimin tanımını "insanların hayatını kolaylaştıran bilgi birikimi” (Ö: \%50, ÖA: \%38), “teknolojinin gelişmesi için kaynak” (Ö: \%30, ÖA: \%25), "gözleme ve deneye dayalı kanttlanmış gerçeklikler" (Ö: \%20, ÖA: \%13), "evrendeki bilinmeyenleri bilinir kılan araştırmalar bütünü” (Ö: 0, ÖA: \%25) şeklinde yapmışlardır. Bilimi insan hayatını kolaylaştıran her şey olarak düşünen bir öğretmen bunu şu şekilde ifade etmiştir:

"Bilim sayesinde ortaya çıkan pek çok şey insanların hayatlarını kolaylaştırır. Çok basit bir örnek vermek gerekirse bulaşık makinesi sayesinde gereksiz şeylerle uğraşıp yorulmak yerine insanlar kendilerine 
daha fazla vakit ayırabiliyorlar" (Ö2).

Bilimin önemi ile ilgili görüşme sorusuna öğretmen ve öğretmen adayları genellikle ortak görüşler ortaya koymuşlardır. Öğretmen adayları bilimin toplumun her alanını etkilediği için önemli olduğu (Ö: \%30, ÖA: \%50), savunurken öğretmenler daha çok bilimin pek çok bilinmeyen gerçeklikleri ortaya çıkardığı için önemli olduğu (Ö: \%40, ÖA: \%13) şeklinde görüşler ortaya koymuşlardır. Bilimin insanların hayatını kolaylaştırdığı için önemli olduğunu da belirtmişlerdir (Ö: \%30, ÖA: \%38). Örneğin görüşmeye katılan bir öğretmen adayı bu soruya şu şekilde cevap vermiştir:

"Bizim bilmediğimiz ama aslında var olan hayatımızdaki gerçeklikleri ortaya çıkardlğg için bilim çok önemlidir. Örneğin, güneş sisteminin yapısını bilim sayesinde biliyoruz. Doğa ve evren hakkında en küçük ayrıntıları bile bilim sayesinde ögrenerek farkındalı kazanabiliriz..." (ÖA5).

Ankette yer alan ikinci kategorideki sorular, toplumun bilim üzerine etkisini; etik ve halkın bilim insanları üzerine etkisini değerlendirmektedir. Tablo 3 öğretmen ve öğretmen adaylarının toplumun bilim ve teknoloji üzerine etkisi üzerine olan görüşlerini sunmaktadır.

Tablo 3. Öğretmen ve Öğretmen Adaylarının Toplumun Bilim ve Teknoloji Üzerine Etkisi Hakkındaki Görüşleri

\begin{tabular}{|l|l|l|l|l|l|l|l|l|}
\hline \multirow{2}{*}{ Madde } & \multicolumn{2}{|l|}{ Yetersiz } & \multicolumn{2}{|l|}{ Kabul Edilebilir } & \multicolumn{2}{l|}{ Gerçekçi } & \multirow{2}{*}{$\boldsymbol{X}^{2}$} & \multirow{2}{*}{$\mathbf{p}$} \\
\cline { 2 - 8 } & $\ddot{\mathbf{O A} \%}$ & $\ddot{\mathbf{O} \%}$ & ÖA\% & $\ddot{\mathbf{O} \%}$ & ÖA\% & O\%\% & & \\
\hline $\mathbf{2}$ & 24,5 & 24,1 & 37,2 & 41,1 & 38,3 & 34,8 & .362 & .834 \\
\hline $\mathbf{3}$ & 7,6 & 14,0 & 35,2 & 30,7 & 57,1 & 55,3 & 2.430 & .297 \\
\hline
\end{tabular}

Tablo 3'e göre öğretmen ve öğretmen adayları bilim etiği üzerine olan 2. madde için gerçekçi ve kabul edilebilir görüşler sunmuşlardır. Halkın bilim insanları üzerine etkisine yönelik olan anket maddesinde ise öğretmenler ve öğretmen adayları gerçekçi görüşler sunmuşlardır. Öğretmen ve öğretmen adaylarının toplumun bilim ve teknoloji üzerine etkisi için hazırlanan anket maddeleri için yapılan Ki-kare testine göre aralarında anlamlı bir fark bulunamamıştır.

Toplumun bilim üzerine etkisine yönelik sorulan görüşme sorusuna öğretmen ve öğretmen adayları bu etkinin bireylerin dini inançları (Ö: \%50, ÖA: \%38), toplumun desteği (Ö: \%10, ÖA: \%38), toplumun gelişmişlik düzeyi (Ö: \%30, ÖA: \%13) ve toplumun ihtiyaçlarından (Ö: \%10, ÖA: \%13) kaynaklandığından bahsetmişlerdir. Dini inançların etkisini açıklayan bir öğretmen bunun için evrim teorisini örnek göstermiştir:

“... toplumdaki bireyler genellikle dini inançlarına aykırı olan çoğu şeyi reddetme eğilimindedirler. Bilimsel buluşlarda da bu durum aynıdır. Örneğin hala Türkiye'de evrim teorisi bir tabudur. Çoğu ögretmen bu konuyu anlatmamayı ya da üstün körü anlatmayı tercih etmektedir" (Ö5).

Anketteki üçüncü kategorideki sorular bilimin toplum üzerine etkisini değerlendirmektedir. Tablo 4'te öğretmen ve öğretmen adaylarının bu kategoriye ait görüşleri görülmektedir. 
Tablo 4. Öğretmen ve Öğretmen Adaylarının Bilimin Toplum Üzerine Etkisi Hakkındaki Görüşleri

\begin{tabular}{|c|c|c|c|c|c|c|c|c|}
\hline \multirow{2}{*}{ Madde } & \multicolumn{2}{|c|}{ Yetersiz } & \multicolumn{2}{|c|}{ Kabul edilebilir } & \multicolumn{2}{|c|}{ Gerçekçi } & \multirow{2}{*}{$X^{2}$} & \multirow{2}{*}{$\mathbf{p}$} \\
\hline & ÖA\% & Ö\% & ÖA\% & Ö\% & ÖA\% & Ö\% & & \\
\hline 4 & 47,1 & 39,8 & 24,5 & 36,3 & 29,4 & 25,6 & 3.493 & .174 \\
\hline 5 & 26,3 & 23,6 & 33,0 & 35,1 & 40,8 & 41,2 & .210 & .900 \\
\hline 6 & 55,0 & 49,1 & 28,0 & 28,4 & 55,0 & 49,1 & 1.492 & .474 \\
\hline
\end{tabular}

Tablo 4 incelendiğinde bilim insanının sosyal sorumluluğu üzerine 4. anket sorusunda öğretmen adaylarının öğretmenlere göre az da olsa daha fazla gerçekçi görüşe sahip olduklarını $(\% 29,4)$ fakat yetersiz cevaplarının öğretmenlere göre daha yüksek olduğu $(\% 47,1)$ fark edilmektedir. Bilimsel olaylarda karar vericilerin kimler olması gerektiği ile ilgili bakış açısını ölçen 5. madde için ve bilim insanının günlük hayatta karşılaştığı problemleri nasıl çözdüğü ile ilgili olan 6 . madde için öğretmen ve öğretmen adaylarının çoğunlukla gerçekçi bakış açısına sahip görüşler ortaya koydukları tablo 4'te görülmektedir. Öğretmen ve öğretmen adaylarının bilimin toplum üzerine etkisi ile ilgili maddeler için yapılan Ki-kare analizine göre görüşleri arasında anlamlı bir farklılık bulunamamıştır.

Görüşmelerde ise öğretmen adayları bilimin toplum üzerine teknolojik ürünler (Ö: \%40, ÖA: \%75) açısında daha etkili olduğunu belirtirken öğretmenler ise bu durumu toplumun yaşam kalitesi (Ö: \%60, ÖA: \%25) açısından olduğu görüşüne cevaplarında daha çok yer vermişlerdir. Teknoloji boyutunu açıklayan bir öğretmen adayının cevabı şu şekildedir:

"Bilim ürettiği bilimsel bilgiyle ya da teknoloji ile insanlarn gündelik sorunlarına çözümler üretmelerini, hayal güçlerini geliş̧irmelerini sağlar ... bu şekilde istesek de istemesek de bilimsel çalışmaların sonucu olan teknolojik ürünler hayatımızın büyük bir kısmına etki eder" (ÖA2).

Anketteki dördüncü kategorideki sorular bilim insanının karakteristik özelliklerini değerlendirmektedir. Tablo 5 öğretmen ve öğretmen adaylarının bu konu hakkındaki görüşlerini sunmaktadır.

Tablo 5. Öğretmen ve Öğretmen Adaylarının Bilim İnsanının Karakteristik Özellikleri Hakkındaki Görüşleri

\begin{tabular}{|c|c|c|c|c|c|c|c|c|}
\hline \multirow{2}{*}{ Madde } & \multicolumn{2}{|c|}{ Yetersiz } & \multicolumn{2}{|c|}{ Kabul edilebilir } & \multicolumn{2}{|c|}{ Gerçekçi } & \multirow{2}{*}{$X^{2}$} & \multirow{2}{*}{$\mathbf{p}$} \\
\hline & ÖA\% & Ö\% & ÖA\% & Ö\% & ÖA\% & Ö\% & & \\
\hline 7 & 16,7 & 16,9 & 0 & 5,0 & 83,4 & 78,2 & 4.876 & .087 \\
\hline 8 & 11,0 & 17,3 & 10,0 & 12,7 & 79,0 & 70,0 & 2.355 & .308 \\
\hline 9 & 58,2 & 60,4 & 16,3 & 9,4 & 25,5 & 30,1 & 2.339 & .311 \\
\hline
\end{tabular}

Anketin 7. maddesi öğretmen ve öğretmen adaylarının bilim insanlarının açık fikirli, mantıklı, önyargısız ve tarafsız olma özelliklerine yönelik gerçekçi bir bakış açısına sahip olduklarını göstermektedir. Bilim insanlarının aile ve sosyal hayatları ile ilgili olan 8 . madde için de bu durum değişmemektedir. Bilimsel buluşlarda cinsiyetin etkisinin olup olmadığını ölçen 9 . maddede öğretmenlerin \%60,4'ü, öğretmen adaylarının da \%58,2'si kadın ve erkeklerin ihtiyaçlarının ve ilgi alanlarının farklı olduğunu ifade eden yetersiz bakış açısını ortaya koymuşlardır. Bununla birlikte, öğretmenlerin $(\% 30,1)$ daha çok öğretmen adaylarına $(\% 25,5)$ göre daha çok gerçekçi görüşe sahip oldukları tespit edilmiştir. Tablo 5 incelendiğinde öğretmen ve 
öğretmen adaylarının bu kategoride yer alan maddeler için yapılan Ki-kare analizine göre görüşleri arasında anlamlı bir farklılık olmadığı görülmektedir.

$\mathrm{Bu}$ kategoriye ait 3 görüşme sorusundan birincisi için öğretmen ve öğretmen adaylarının cevapları incelendiğinde her iki grubun da bilim insanlarının bilimsel çalışmalar yaparken hayal güçlerini ve yaratıcılıklarını kullandıkları konusunda hemfikir oldukları görülmektedir. Bu yeteneklerini bilimsel araştırmalarda hangi aşamalarda (planlama: Ö: \%60, ÖA: \%63; yorumlama: Ö: \%30, ÖA: \%13; gözlem yapma: Ö: \%20, ÖA: \%25; deney yapma: Ö: \%10, ÖA: \%13) kullandıklarına dair yapmış oldukları sıralamada da benzer sonuçlar elde edilmiştir.

Öğretmen ve öğretmen adayları bilim insanının başarılı olması için taşıması gereken özellikler ile ilgili ortak söylemlerde bulunmuşlardır. Öne çıkan özellikler bilim insanının meraklı (Ö: \%19, ÖA: \%23), yaratıcı (Ö: \%19, ÖA: \%18), tarafsız (Ö: \%19, ÖA: \%14), açık görüşlü (Ö: \%16, ÖA: \%14), azimli (Ö: \%9, ÖA: \%18), disiplinli (Ö: \%9, ÖA: \%9), şüpheci (Ö: \%9, ÖA: \%5) olmasıdır. Bir öğretmen adayı bir bilim insanın karakteristik özelliklerini şu şekilde tanımlamıştır:

"Bence en önemlisi azimli olmasıdır. Çünkü biliyoruz ki en büyük buluşlar bilim insanlarının bıkmadan usanmadan çalışmaları tekrar tekrar yapmaları ile ortaya çıkmışıı. Tabi bu da tek başına yeterli olmaz. Azimli olmasının yanında yaratıcllı, merak, sabır gibi özelliklerde önemlidir" (ÖA5).

$\mathrm{Bu}$ kategorideki bilim insanlarının aile ve sosyal hayatlarının olup olmaması ile ilgili soruya öğretmen ve öğretmen adayları genel anlamda bu durumun bilim insanına bağlı olduğunu (Ö: \%50, ÖA: \%38) düşünürken bir öğretmen bu durumu "Bilim insanlarının aile ve sosyal hayatları her bilim insanının karakterine, çalışma prensibine ve yaşam algısına göre değişiklik gösterir" (Ö7) şeklinde ifade etmiştir.

Bazı katılımcılar onların bir aile hayatının olmadığını (Ö: \%30, ÖA: \%38), bazıları ise bir aile olduğunu (Ö: \%20, ÖA: \%25) belirtmişlerdir.

VOST-TR anketinin bilimsel bilginin sosyal yapısı ile ilgili kategorisinde rekabet ve sosyal ilişkiler değerlendirilmiştir. Tablo 6 öğretmen ve öğretmen adaylarının bilim insanlarının paylaşma, dürüstlük, bağımsızlık gibi bilimin kurallarını çiğnemeleri ve sosyal ilişkileri ile bilimsel çalışmalar arasındaki ilişkinin nasıl olduğuna dair görüşleri verilmiştir.

Tablo 6. Öğretmen ve Öğretmen Adaylarının Bilimsel Bilginin Sosyal Yapısı Hakkındaki Görüşleri

\begin{tabular}{|c|c|c|c|c|c|c|c|c|}
\hline \multirow{2}{*}{ Madde } & \multicolumn{2}{|c|}{ Yetersiz } & \multicolumn{2}{|c|}{ Kabul edilebilir } & \multicolumn{2}{|c|}{ Gerçekçi } & \multirow{2}{*}{$X^{2}$} & \multirow{2}{*}{$\mathbf{p}$} \\
\hline & ÖA\% & Ö\% & ÖA\% & Ö\% & ÖA\% & Ö\% & & \\
\hline 10 & 42,6 & 27,8 & 50,5 & 62,6 & 6,9 & 9,6 & 5.202 & .074 \\
\hline 11 & 18,3 & 39,9 & 50,0 & 31,7 & 31,7 & 23,3 & 3.742 & .154 \\
\hline
\end{tabular}

Tablo 6 incelendiğinde rekabet ile ilgili 10. maddede öğretmenlerin ve öğretmen adaylarının kabul edilebilir bir bakış açısına sahip oldukları ortaya çıkmıştır. Bilim insanlarının sosyal ilişkileri ile ilgili 11. maddede öğretmenlerin yetersiz $(\% 39,9)$, öğretmen adaylarının ise kabul edilebilir (\%50) görüşlere sahip oldukları görülmektedir. Rekabet $\left(X^{2}=5.202 ; \mathrm{p}=.074\right)$ ve bilim insanının sosyal ilişkileri $\left(X^{2}=3.742 ; \mathrm{p}=.154\right)$ ile ilgili anket maddeleri için öğretmen ve öğretmen adaylarının görüşleri arasında Ki-kare testi analizinde anlamlı bir farklılık bulunamamıştır. 
Öğretmen ve öğretmen adayları ile yapılan görüşmede katılımcıların yarısından fazlası bilim insanlarının yeni bir teoriyi kabul etme sürecinde güdülerinden ve kendi görüşlerinden etkilenmemesinin imkânsız olduğunu vurgulamışlardır (Ö: \%70, ÖA: \%63). Bu konu ile ilgili bilimin yüzde yüz nesnel olamayacağına dikkat çeken öğretmen adayı ise şunları söylemiştir:

"Bilim insanları bir çalı̧̧ma yaptıklarında bu çalışmanın sonuçlarını kendi öznel görüşlerine göre değerlendirirler. Bir teori öne sürüldügü̈nde de kişisel güdüleri devreye girer. Zaten bunlardan dolayı bilim yüzde yüz nesneldir diyemeyiz" (ÖA4).

Bilim insanının karakteristik özellikleri kategorini temsil eden bilim insanlarının bilimsel etik ile ilişkisi hakkında, katılımcıların tümü bilim insanlarının bilimin paylaşma, dürüstlük ve bağımsızlık gibi kurallarını çiğneyebileceklerini ifade etmişlerdir. Bunu, bilim insanlarının diğer bilim insanları ile rekabet içinde olmalarına, başarı duygusunu yaşama isteklerine ve bazı otoritelerin baskılarına bağlamaktadırlar. Bir öğretmen adayı bu görüşü "Bilim dünyasında çok ciddi bir rekabet ortamının olduğunu düşünüyorum. Insanlar çalışlyorlar ve doğal olarak bunun karşılığını almak istiyorlar. Bu rekabet duygusu insanları aslında istemedikleri şeyleri yapmaya sevk edebilir" şeklinde ifade etmiştir (ÖA5).

Son olarak öğretmen ve öğretmen adaylarının bilimsel bilginin karakteristik özellikleri ile ilgili görüşleri VOST-TR anketinin 12-25. sorularında değişik başlıklar altında incelenmiştir.

Tablo 7. Öğretmen ve Öğretmen Adaylarının Bilimsel Bilginin Karakteristik Özellikleri Hakkındaki Görüşleri

\begin{tabular}{|c|c|c|c|c|c|c|c|c|}
\hline \multirow{2}{*}{ Madde } & \multicolumn{2}{|c|}{ Yetersiz } & \multicolumn{2}{|c|}{ Kabul edilebilir } & \multicolumn{2}{|c|}{ Gerçekçi } & \multirow{2}{*}{$X^{2}$} & \multirow{2}{*}{$\mathbf{p}$} \\
\hline & ÖA\% & $\ddot{O} \%$ & ÖA\% & Ö\% & ÖA\% & Ö\% & & \\
\hline 12 & 7,6 & 8,7 & 20,0 & 21,5 & 72,4 & 69,8 & .182 & .913 \\
\hline 13 & 75,8 & 82,3 & 9,7 & 4,4 & 14,6 & 13,2 & 2.604 & .272 \\
\hline 14 & 41,9 & 34,8 & 3,8 & 8,0 & 54,3 & 57,1 & 2.950 & .229 \\
\hline 15 & 9,6 & 20,9 & 6,7 & 8,2 & 83,8 & 70,9 & 5.861 & .053 \\
\hline 16 & 90,5 & 79,0 & - & - & 9,5 & 20,9 & 5.359 & .021 \\
\hline 17 & 9,6 & 6,2 & 65,4 & 67,3 & 23,1 & 14,2 & .888 & .642 \\
\hline 18 & 6,8 & 11,4 & 54,8 & 50,0 & 38,5 & 38,6 & 1.535 & .464 \\
\hline 19 & 26,7 & 18,4 & 45,7 & 49,2 & 27,6 & 32,5 & 2.219 & .330 \\
\hline 20 & 37,9 & 29,3 & 37,9 & 48,3 & 24,3 & 22,4 & 2.642 & .267 \\
\hline 21 & 10,6 & 11,2 & 36,5 & 30,2 & 52,9 & 58,6 & 1.012 & .603 \\
\hline 22 & 33,9 & 37,9 & 39,8 & 29,3 & 26,2 & 32,8 & 2.778 & .249 \\
\hline 23 & 64,9 & 73,6 & 26,6 & 21,3 & 8,5 & 4,6 & 2.377 & .305 \\
\hline 24 & 50,0 & 54,0 & 29,7 & 32,0 & 20,2 & 14,0 & 1.325 & .516 \\
\hline 25 & 30.2 & 14.3 & 33.3 & 52.4 & 38.5 & 33.3 & 9.180 & .010 \\
\hline
\end{tabular}

Tablo 7 incelendiğinde öğretmen ve öğretmen adaylarının anketin bu kategorisine ait görüşlerinin genel anlamda birbirine yakın olduğu görülmektedir. Bu durum sadece bilimsel kanunlara icat ya da keşif yoluyla mı ulaşıldığıyla ilgili olan 22. maddede değişiklik göstermektedir. Bu 
madde için öğretmenlerin yetersiz $(\% 37,9)$, öğretmen adaylarının ise kabul edilebilir $(\% 39,8)$ görüşe sahip oldukları tespit edilmiştir.

Öğretmen ve öğretmen adayları, bilim insanının sahip olduğu inançlar ile yapılan gözlemler arasındaki ilişki ile ilgili görüşleri ile ilgili 12. madde, bilim insanlarının doğada yaptıkları sınıflandırmalarla ilgili bakış açılarını ölçen 14. madde, bilimsel bilginin değişebilirliği ile ilgili görüşlerini tespit eden 15. madde ve bilimsel bilginin kesinliği ile ilgili olan 21 . maddede öğretmen ve öğretmen adaylarının daha çok gerçekçi görüşler belirttikleri görülmektedir.

Bilimsel bilginin gelişmesi için tahminlerin etkisi ile ilgili görüşleri ölçmeyi hedefleyen 17. madde, teorilerin özellikleri ile ilgili katılımcıların görüşlerini ölçmeyi hedefleyen 18. madde, bilimsel yöntemin basamaklarına yönelik 19. madde ve bilim insanlarının hata yapıp yapmamalarının bilimsel bilgiye nasıl bir etkisinin olabileceği ile ilgili görüşlerini belirlemeyi hedefleyen anketin 20. maddesi için öğretmen ve öğretmen adaylarının kabul edilebilir görüşler ortaya koydukları görülmektedir.

Bilimsel modellerin gerçeğin kopyası olup olmadığ ile ilgili olan 13. madde, hipotez, teori ve kanun arasında bir hiyerarşi olup olmadığı ile ilgili görüşleri ölçen 16. madde, hipotezlerin icat $\mathrm{m} 1$ ya da keşif yoluyla $\mathrm{m}$ elde edildiği ile ilgili görüşleri ölçmeyi amaçlayan 23 . madde, teorilerin bilim insanlarının icatları mı yoksa keşifleri mi olduklarını araştıran 24. madde için her iki grup da yetersiz görüşe sahip bulunmuştur.

Öğretmen ve öğretmen adaylarının görüşleri arasında anlamlı bir fark olup olmadığını görebilmek için yapılan Ki-kare analizlerinde anlamlı fark sadece 16. ve 25. maddelerinde tespit edilmiştir. Tablo 7'ye göre 16. madde için her iki grupta yüksek oranda yetersiz görüşler ortaya koymalarına rağmen, öğretmen adaylarının (\%90,5) öğretmenlere göre (\%79) daha çok yetersiz görüşe yani hipotez, teori ve kanun arasında hiyerarşik bir ilişki olduğuna inandıkları görülmektedir. Aynı zamanda öğretmenlerin $(\% 20,9)$ öğretmen adaylarına göre $(\% 9,5)$ daha çok gerçekçi görüşe sahip oldukları görülmektedir.

Öğretmen ve öğretmen adaylarının bilimsel çalışmaların bilim insanlarının bakış açıları ile olan ilişkisi ile ilgili görüşleri belirlemeyi hedefleyen anketin son maddesi için yapılan Ki-kare analizine göre de görüşler arasında anlamlı farklılık bulunmuştur $\left(X^{2}=9.180 ; \mathrm{p}=.010\right)$. Öğretmenlerin $(\% 52,4)$ öğretmen adaylarına $(\% 33,3)$ göre daha çok kabul edilebilir bakış açısına sahip oldukları görülmektedir. Öğretmenlerin büyük bir kısmının farklı alanlardaki bilimsel düşüncelerin örtüştüğünü, bu nedenle bilim insanlarının birbirlerini anlamalarının kolay olduğunu düşündükleri tespit edilmiştir. Öğretmen adaylarının ise öğretmenlere göre daha çok yetersiz görüşler ortaya koydukları görülmektedir. Öğretmen adaylarının büyük bir kısmının bilim insanları farklı alanlarda farklı dil kullandıkları için onların birbirlerini anlamalarının zor olduğuna inandıkları ortaya çıkmıştır.

Bu kategoriye ait görüşmelerde 3 soru yöneltilmiştir. Hipotez-teori-kanun arasındaki ilişkiye yönelik olan soruda Ö4 ve ÖA1 hariç katılımcıların hepsi hipotez-teori-kanun arasında bir hiyerarşi olduğunu belirtmişlerdir:

"Hipotezler varsayımlardır. Bunlar deneysel yöntemlerle kanıtlandıkları zaman teori olurlar. Insanlık tarafindan kabul gördükleri zamanda kanun olurlar. Yani kanun olmaları için evrensel özellik taşımaları gerekir" (Ö6).

Bilimsel bilginin değişebilirliği ile ilgili soruda ise katılımcıların tümü bilimsel bilginin durağan olmayıp sürekli gelişip değişmekte olduğunu belirten açılamalar yapmışlardır: 
"Yeni bilimsel yöntemlerin ortaya çıkması ve araştırmaların derinleşmesi doğal olarak var olan bilimsel bilginin kökten değişmesine ya da gelişerek değişmesine neden olmaktadır" (Ö7).

Bilimsel bilginin karakteristik özelliklerinden bilimsel yöntem ile ilgili yöneltilen soruya verilen cevaplarda iki temel görüş ortaya çıkmıştır. Öğretmen ve öğretmen adayları genel anlamda daha çok bilimsel yöntemi bilim insanlarının kullandığı stratejiler, teknikler ve yollar olarak tanımlamışlardır (Ö: \%60, ÖA: \%50). Örneğin bir öğretmen bu soruya, "bir bilim insanının yaptı̆̆ araştırması için izlediği her aşama kullandı̆̆ı tüm teknik ve stratejiler bilimsel yöntemi kapsar..." (Ö7) şeklinde cevap vermiştir.

İkinci görüş ise bilimsel yöntem yöntemin bilimsel araştırma basamakları olarak tanımlayanlara aittir (Ö: \%40, ÖA: \%50). Bilimsel yöntemin bilimsel araştırma basamaklarının tümü olduğu görüşünü ise bir öğretmen şu şekilde ifade etmiştir:

"En temel fen eğitimi kitaplarında karşımıza çıkan problemi fark etme, hipotezi kurma, verileri toplama, verileri analiz etme ve sonuçlara ulaşma gibi bilimsel süreçlerin tümüdür..." (Ö9).

Sorunun ikinci kısmında yöneltilen bilim insanları tarafından kullanılan tek bir bilimsel yöntem olup olmadığı ile ilgili soruya ise katılımcıların tümü tek bir bilimsel yöntemin olamayacağ yönünde görüşler bildirmişlerdir. Bir öğretmen aday1, “...her bilim insanının kendine göre kullandığı bir bilimsel yol vardır. Ayrıca bilim insanı yapacağı çalışmanın niteliğine ya da amacına göre bilimsel bir yol belirler" (ÖA3) şeklinde cevap vermiştir.

\section{Sonuç ve Tartışma}

$\mathrm{Bu}$ çalı̧̧ma kapsamında, sınıf öğretmenlerinin ve sınıf öğretmeni adaylarının bilimin doğası konusundaki bilim, toplumun bilim üzerine etkisi, bilimin toplum üzerine etkisi, bilim insanının karakteristik özellikleri, bilimsel bilginin sosyal yapısı ve bilimsel bilginin karakteristik özellikleri ile ilgili bakış açıları VOST-TR anketi ile belirlenmeye çalışılmıştır.

Öğretmen ve öğretmen adayları anketin 9 maddesi için gerçekçi, 9 maddesi için kabul edilebilir ve 7 maddesi için yetersiz bakış açılarını yansıtan görüşler ortaya koymuşlardır. Yetersiz görüşlerin büyük oranda bilimsel bilginin karakteristik özellikleri yani bilimsel bilginin doğası ile ilgili maddelerde ortaya çıktığı görülmektedir. Yapılan Ki-kare testlerinde ise sadece bilimsel bilginin karakteristik özellikleri ile ilgili kategoride yer alan iki maddede öğretmen ve öğretmen adaylarının görüşleri arasında anlamlı fark tespit edilmiştir. Görüşmelerde ise bilimin toplum üzerine etkisi kategorisi haricinde tüm kategorilerde öğretmen ve öğretmen adayları benzer görüşler bildirmişlerdir.

Öğretmen ve öğretmen adayları bilimin tanımı ile ilgili ortak bir görüş ortaya koyamamakla birlikte büyük oranda kabul edilebilir görüşlere sahiptirler. Literatürde bulunan pek çok çalışmada katılımcıların bilimin ortak bir tanımı yapamadıkları ve genel anlamda gerçekçi olmayan görüşlere sahip oldukları görülmektedir (Doğan-Bora 2005; Kenar 2008; Beşli 2008; Aslan 2009; Ar1 2010; Çınar \& Köksal 2013). Yapılan bu çalışmada da öğretmen ve öğretmen adaylarının bilimin tanımı konusunda çağdaş bakış açısına sahip olmadıkları görülmektedir.

Toplumun bilim üzerine etkisi ile ilgili anket kategorisindeki maddelere göre öğretmen ve öğretmen adaylarının bilimsel çalışmaların yapıldığı yerdeki dini, ahlaki ve kültürel öğelerden etkilendiğini belirten görüşler ortaya koymuşlardır. Benzer şekilde, Aikenhead (1987), DoğanBora (2005), Beşli (2008), Aslan (2009) ve Çınar ve Köksal (2013) yaptıkları çalışmalarda katılımcıların toplumun bilimsel araştırmaları etkilediği yönde görüşler belirtiklerini bulmuşlardır. 
Oysaki Lederman vd. (2002) ve Liu ve Lederman (2007) yaptıkları araştırmalarda sosyal ve kültürel değerlerin bilime etkisinin olmadığ 1 görüşlerini tespit etmişlerdir. Yine aynı kategoride yer alan bir diğer maddeye öğretmen ve öğretmen adaylarının verdikleri cevaplara göre ailelerin, toplumun ve okulun yetiştirme tarzlarının bilim insanına etkisi ile ilgili gerçekçi görüşe sahip oldukları görülmektedir. Yetiştirme tarzı ile ilgili sonuç Doğan-Bora'nın (2005), Beşli'nin (2008) ve Aslan'ın (2009) fen bilgisi öğretmen ya da öğretmen adayları ile yaptığı araştırmaların sonuçları ile paralellik göstermektedir.

Bilimin toplum üzerine etkisi ile ilgili öğretmen ve öğretmen adayları bilim insanının sosyal sorumluluğu ile ilgili yetersiz görüşler belirtirken, sosyal kararlar ve günlük problemlerin çözümü ile ilgili maddelere gerçekçi görüşler sunmuşlardır. Bilimsel olaylarda verilecek kararlarda uzmanların ve bilgilendirilmiş toplumun görüşlerinin eşit oranda dikkate alınması gerektiği gerçekçi görüşü ögretmen ve öğretmen adayları tarafından yüksek ve benzer oranda ortaya konmuştur. Fakat Beşli'nin (2008) araştırmasında bu madde için belirtilen görüşlerde sadece bilim insanlarının karar alması fikrini savunan katılımcıların daha fazla olduğu görülmektedir. Son olarak, bu kategoriyi ifade eden bilim insanlarının karşılaştıkları gündelik problemleri en iyi şekilde çözüp çözmedikleri ile ilgili madde için öğretmen ve öğretmen adayları problem çözme becerileri avantaj sağlayacağı için bilim insanlarının bu konuda diğer insanlardan daha bilgili olduklarını ifade eden gerçekçi görüşünü daha çok ortaya koymuşlardır. Öğretmen adaylarının ise bu madde için öğretmenlere göre daha çok gerçekçi görüşe sahip oldukları görülmektedir. Beşli de (2008) araştırmasında benzer sonuca ulaşırken, Doğan-Bora (2005) çalışmasında fen bilgisi öğretmen ve öğretmen adaylarının bilim insanlarının günlük yaşantıdan uzak yaşayarak çalıştıkları için daha kötü olabileceklerini düşündükleri tespit etmiştir.

Bilim insanının karakteristik özellikleri ile ilgili olarak başarılı bilim insanlarının araştırmalarında daima çok açık fikirli, mantıklı, önyargısız ve tarafsız olması konusunda öğretmen ve ögrretmen adayları büyük oranda gerçekçi görüşlere sahip oldukları görülmüştür. Bu durum Doğan-Bora'nın (2005) ve Aslan'ın (2009) yaptığı araştırmalarla paralellik göstermektedir. $\mathrm{Bu}$ bakış açısına göre, öğretmen ve öğretmen adayları başarılı bilim insanında hem bu özellikleri hem de ek olarak hayal gücü, zekâ, dürüstlük gibi başka özelliklerin de olması gerektiğini düşünmektedirler. Bunun yanında Doğanay, Demircioğlu ve Yeşilpınar'ın (2014) araştırmasında bilim insanının objektif olması ilk belirtilen özellik olmuştur.

Son olarak bu kategori ile ilgili bilimsel buluşlarda cinsiyetin etkisinin olup olmadığ ilgili görüşlerin alındığı madde için katılımcıların yarısından fazlası kadın ve erkeklerin ihtiyaçlarının ve ilgi alanlarının farklı olduğunu ifade eden yetersiz bakış açısını ortaya koymuşlardır. Doğan-Bora (2005) ve Beşli de (2008) araştırmalarında benzer sonuçlara ulaşmışlardır. Bu durum ne yazık ki ülkemizde eğitim düzeyleri yüksek bireyler arasında bile hala daha erkeklerin kadınlardan üstün olduğunu yansıtan görüşlerin yaygın olduğunu göstermektedir.

Bilimsel bilginin sosyal yapısı ile ilgili ankette yer alan maddeler için katılımcıların genellikle kabul edilebilir görüşlere sahip oldukları görülmüştür. Katılımcılar rekabet ve başarı isteğinden dolayı ya da duruma bağlı olarak bilim insanlarının bazen bilimin kurallarını çiğnediklerini düşündüklerini belirten kabul edilebilir görüsse sahiptirler. Beşli (2008) bu sonucun biraz da sorunun yapısından kaynaklandığını düşünmektedir.

Bunlarla birlikte birçok bilim insanının birbiriyle işbirliği yaparak yarışmadıkları düşüncesini ifade eden gerçekçi görüşleri hem öğretmenlerin hem de öğretmen adaylarının çok az oranlarda ortaya koymuş olmaları dikkat çekmiştir. Bu durumun, günümüz toplumunda rekabetin artık kaçınılmaz olmasından kaynaklandığı düşünülmektedir. Özellikle son yıllarda öğretmenlerin atanmaları sırasında yaşanan rekabetin bu sorunun cevabına da yansıdığı düşünülmektedir. 
Bilim insanının sosyal ilişkileri ile bilimsel çalışmalar arasındaki ilişki için bu ilişkilerin bilim insanlarını gözlem yapmaya teşvik ettiği ve toplumsal araştırmalar için teşvik ettiği düşüncesini ifade eden kabul edilebilir görüşlere öğretmen adaylarının öğretmenlerden daha çok sahip oldukları tespit edilmiştir. Doğan-Bora'nın (2005) fen bilgisi öğretmenleri ve adayları ile ilgili yaptığ

Bilimin doğası ile ilgili özellikler içinde ankette en çok yer alan bilimsel bilginin karakteristik özellikleri yani bilimsel bilginin doğası ile ilgili görüşlerin daha çok kabul edilebilir ve yetersiz görüşler olduğu görülmektedir. Bu sonuç da uluslararası ve ulusal araştırmalarda elde edilen sonuçlarla paralellik göstermektedir (Eve \& Dunn 1990; King 1991; Lederman 1992; Abd-El-Khalick \& Boujaoude 1997; Moss, Abrams \& Robb 2001; Taşar 2003; Çelik 2003; Doğan-Bora 2005; Gürses, Doğar \& Yalçın 2005; Kang, Scharmann \& Noh 2005; Çelikdemir 2006; Beşli 2008; Doğan, Akçay, Kaya \& Öcal 2008; Aslan 2009; Aslan, Yalçın \& Taşar 2009).

Bilim insanlarının sahip oldukları inançların yaptıkları gözlemler üzerine etkisi ile ilgili öğretmen ve öğretmen adayları bilim insanları farklı deneyler yaptıkları ve birbirlerinden farklı düşündükleri için gözlemlerinin de farklı olacağını ifade eden gerçekçi görüşler belirtmişlerdir. Aslan (2009) bu durumu aynı nesneye veya manzaraya aynı yerden bakan iki gözlemcinin aynı şeyleri görebilecekleri düşünülse de gözlemcilerin gördüğü şeyin, geçmiş tecrübelerine, bilgisine ve beklentilerine bağlı olduğu şeklinde açıklamaktadır.

Bilimsel modellerin gerçeğin kopyası olup olmadığı ile ilgili öğretmenlerin ve öğretmen adaylarının büyük bir kısmının bilimsel modellerin gerçeğin kopyası olduğunu yansıtan yetersiz görüşlere sahip oldukları görülmüştür. Literatürde bilimin doğası ile ilgili bu özelliğin ölçüldüğü pek çok çalışmada katılımcıların bu konuda yetersiz görüşlere sahip oldukları bulunmuştur (Palmquist \& Finley 1997; Yakmac1 1998; Lederman et al. 2002; Erdoğan 2004; Doğan 2005; Küçük 2006; Kaya 2007; Ayvacı 2007; Liu \& Lederman 2007; Çınar \& Köksal 2012; Doğanay, Demircioğlu \& Yeşilpınar 2014). Bilim insanlarının doğada yaptıkları sınıflandırmalarla ilgili ise öğretmen ve öğretmen adaylarının yarısından fazlasının gerçekçi görüşlere sahip oldukları ortaya çıkmıştır. Bu sonuç da Yakmacı (1998), Erdoğan (2004), Doğan (2005) ve Aslan'ın (2009) çalışmalarının sonuçları ile örtüşmektedir.

Bilimsel bilginin değişebilirliği ile ilgili katılımcıların çok büyük bir kısmının eski bilgiler yeni buluşlar 1şığında yeniden yorumlanacağ 1 ve bilim insanları yeni teknikler kullanarak eski teorileri çürütebileceği için bilimsel bilginin değiştiğini belirten gerçekçi görüşlere sahip oldukları görülmektedir. $\mathrm{Bu}$ sonuçlar literatürdeki diğer araştırmalarla benzer özellikler göstermektedir (Doğan-Bora 2005; Beşli 2008; Aslan 2009). Bununla birlikte Doğan-Bora'nın (2005) çalışmasından elde ettiği sonuçlarda olduğu gibi bu araştırmada da öğretmenlerin öğretmen adaylarına göre daha çok yetersiz görüşe sahip oldukları dikkat çekmiştir. Bu durumun birçok değişkenden -örneğin yaş, kıdem, mezun olunan okul vb.- etkilendiği düşünülmektedir. Literatürde bu değişkenleri dikkate alarak yapılan araştırmalar bu özelliklerin sonuçları etkilediğini ortaya koymaktadır (Doğan-Bora 2005).

Hipotez, teori ve kanun arasında bir hiyerarşi olup olmadığ 1 ile ilgili öğretmen ve öğretmen adaylarının çoğunluğu yetersiz görüşler oraya koymuşlardır. Öğretmenlerin \%46,3'ü, öğretmen adaylarının da \%71,4'ü "hipotez teoriye, teori kanuna dönüşebilir" yetersiz görüşünü belirtirken, öğretmenlerin \%32,7'si, öğretmen adaylarının da \%19'1 doğruluğu kanıtlanamayacağı için teorilerin kanuna dönüşemeyeceğini, kanunların \%100 kesinliği olduğunu ifade eden yetersiz görüşü ortaya koymuşlardır. Bu durum McComas'ın da (2003) belirttiği gibi bilimsel fikirlerin hiyerarşik bir yapısının bulunduğu ile ilgili yanlış inanışla açıklanabilir. Oysaki hipotez, teori ve kanunlar farklı bilimsel bilgilerdir. Bilimsel bilgilerde hipotezden teoriye ve 
kanunlara giden hiyerarşik bir yapılanma olduğunu savunan geleneksel anlayışa öğretmen adaylarının büyük bir kısmının sahip olduğu görülmektedir. Hipotez-teori ve yasa arasında bir hiyerarşi olduğu kavram yanılgısına literatürdeki araştırmalarda da oldukça sık rastlanmaktadır (Erdoğan 2004; Doğan 2005; Liu \& Lederman 2007; Kenar 2008; Aslan 2009; Tatar, Karakuyu \& Tüysüz 2011). Bu madde için öğretmenlerle öğretmen adaylarının görüşleri arasında anlamlı farklılıklar olduğu görülmektedir. Her iki grupta yüksek oranda yetersiz görüşler ortaya koymalarına rağmen, öğretmen adaylarının öğretmenlere göre daha çok yetersiz görüşe sahip oldukları görülmektedir.

Bilimsel bilginin gelişmesi ile tahminler arasındaki ilişki ile ilgili öğretmenlerin ve öğretmen adaylarının daha çok kabul edilebilir görüşlere sahip oldukları görülmüştür. Aynı şekilde, teorilerin özellikleri ile ilgili de katılımcılar, teorilerin amacına göre basit ya da karmaşık olabileceğini ifade eden kabul edilebilir görüşler ortaya koymuşlardır. Bilimsel yöntem basamakları ve bilim insanlarının çalışmalarındaki hatalar ile ilgili katılımcılar genel olarak kabul edilebilir görüşler yansıtmışlardır. Öğretmen ve öğretmen adayları bilim insanlarının geçerli, açık, mantıklı sonuçlar sağlaması ve bilimsel yöntemin birçok bilim insanı için uygun olması nedenleriyle bilimsel yöntem basamaklarının kullanıldığı kabul edilebilir görüşlerini belirtmişlerdir. Abd-El Khalick (2001) bir çalışmasında "Katılımcılar doğru ve kesin bilgiye tek bir bilimsel yöntemle ulaşabilir" şeklindeki geleneksel görüşünü tespit etmiştir. Öğretmen ve öğretmen adayları "hatalar bilimin ilerlemesini yavaşlatır" ve "bazı hatalar yeni ve büyük buluşlara neden olabilir" şeklinde ifade ettikleri kabul edilebilir görüşlere sahip bulunmuştur.

Bilimsel bilginin kesinliği ve belirsizliği ile ilgili hem öğretmen hem de öğretmen adaylar1nın yarısından fazlası gerçekçi görüşler belirtmişlerdir. Katılımcılar bu konu hakkında, kimsenin geleceği kesin olarak tahmin edemeyeceğini ve bazı bilgilerin daima eksik olduğunu düşünmektedirler. Yapılan görüşmelerde de katılımcıların tümü bilimsel bilginin kesin olamayacağını, zamanla değişeceğini yansıtan görüşler ortaya koymuşlardır.

Bilimsel bilginin epistemolojik durumu ile ilgili görüşleri ortaya çıkarmayı hedefleyen maddede için de katılımcıların yetersiz görüşlere sahip oldukları tespit edilmiştir. Kaya (2007) da çalışmasında ön-testlerde öğretmen adaylarının bilimsel bilginin epistemolojik durumu hakkında yetersiz olduğu sonucuna ulaşmıştır. Çalışmanın bu sonucuna benzer sonuçlara başka araştırmalarda da rastlanmaktadır (Ryan \& Aikenhead 1992; Yakmacı 1998; Erdoğan 2004; Doğan 2005; Aslan 2009).

Araştırmaya katılan öğretmenler ve öğretmen adaylarının büyük bir çoğunluğu aynı zamanda teoriler ve kanunlar arasındaki ilişkiyi hiyerarşik ilişki olarak algılamakta ve teorilerin daha fazla kanıta bağlı olarak kanuna dönüşeceğini düşünmektedirler. Bu nedenle de, kanunların teorilerden daha üst seviyede bir kategoriye ait olduğu düşüncesine sahiptirler (Lederman et al. 2002). Gürses, Doğar ve Yalçın'ın (2005) yükseköğretim öğrencileri ile yaptığı bir çalışmada ise katılımcıların teori, kanun ve ispat konusunda hem bilgi eksikliği hem de oldukça fazla kavram yanılgılarına sahip olduğu tespit edilmiştir. Yükseköğretim öğrencileriyle yapılan bu çalışmada olduğu gibi bu araştırmada da öğretmen ve öğretmen adaylarının hipotez, teori ve kanunların her zaman doğada açığa çıkartılmayı beklediğini ve bilim insanlarının onları keşfettiğini ifade eden çağdaş olmayan görüşler ortaya koymuşlardır. Araştırmalarda, hipotez, teori, kanun arasındaki ilişkilere ait kavram yanılgıların ders kitaplarında yer alan yanlış ifadelerin veya öğretmenlerin önemli rolü olduğu ifade edilmiştir (Zeidler \& Ledermann 1989; Ryan \& Aikenhead 1992; İrez 2009; Taşkın et al. 2010). Öğretmen ve öğretmen adaylarının sahip oldukları hipotez, teori ve kanunların doğada hazır olduğu ile ilgili kavram yanılgılarına dayanarak onların bilimi dolaylı kanıtlardan çok, doğrudan kanıtlara dayanan ve doğada var 
olan gerçekleri keşfetmekten oluşan bir süreç olarak algıladıkları düşünülebilir. Sahip oldukları algılayış biçimi, pozitivist bir epistemoloji anlayışı ile açıklanabilir. Bu görüş bilimsel bilginin yalnızca birikerek geliştiğini ve bilimin olgusal gerçekleri keşiften ibaret olduğunu savunmaktadır (Abd-El-Khalick \& Lederman 2000; Kang et al. 2005).

Bilimsel çalışmaların bilim insanlarının bakış açıları ile olan ilişkileri hakkında öğretmenlerin çoğunun kabul edilebilir görüşlere, öğretmen adaylarının da çoğunun gerçekçi görüşlere sahip oldukları görülmüştür. Katılımcılar genel olarak, bilim insanlarının zeki oldukları, aynı anda değişik alanlarda çalışmış olabilecekleri ve bilimsel düşünceleri örtüşen bilim insanlarının birbirlerini anlamalarının kolay olduğunu düşünmektedirler. Bilimler arası kavramların tutarlılığı ile ilgili bu madde için öğretmenler ile öğretmen adaylarının görüşleri arasında anlamlı bir ilişki olduğu görülmüştür. Öğretmen ve öğretmen adaylarına göre değerlendirme yapıldığında ise öğretmenler öğretmen adaylarına göre daha çok kabul edilebilir görüşler ortaya koyarken öğretmen adayları öğretmenlere göre daha çok yetersiz görüşler ortaya koymuşlardır. Bu maddeden elde edilen sonuçlar, sınıf öğretmenliği programında yer alan fen bilimleri ve fen eğitimi derslerinin bilimler arası kavramların tutarlılığı ile ilgili bir farkındalık oluşturamadığını ortaya koymaktadır.

Araştırmanın problemlerinden birisi olmamasına rağmen sınıf öğretmeni ve sınıf öğretmeni adaylarının bilimin doğası ile ilgili görüşlerinin ortaya çıkarılması amacı ile yapılan görüşmeler ve VOSTS (TR) anketi ile elde edilen verilerin analiz edilmesi ile öğretmen ve öğretmen adaylarının bazı kavram yanılgılarına sahip oldukları bulunmuştur. Örneğin bilim insanının karakteristik özellikleri ile ilgili maddede bilimsel araştırmaların cinsiyete göre farklılık gösterdiğini düşüncesinin hâkim olduğu görülmüştür. Toplumun bilim üzerine etkisi ile ilgili olarak da dini ya da ahlaki görüşlerin bilimsel araştırmaları etkilemediğini savunmaktadırlar.

Bu kavram yanılgıları içerisinde özellikle bilimsel bilginin doğası ile ilgili olanlara çok fazla rastlanmaktadır. Örneğin;

- Bilimsel hipotezler, teorilere onlar da yeterince doğrulandıklarında kanunlara dönüşürler

- Teoriler değiş̧ebilir; ancak kanunlar değişmeyen yüzde yüz kesin bilgilerdir.

- Bilimsel modeller gerçeğin kopyalarıdır

- Bilimsel çalışmalarda bilim insanlarının kullandığı tek bir bilimsel yöntem vardır.

- Hipotez, teori ve kanunlar doğada hazır olarak bulunarak bilim insanları tarafindan keşfedilirler.

Daha önce yapılan bazı araştırmalar da, bilimin doğasını oluşturan teori, kanun ve hipotez gibi kavramlar hakkında katılımcıların ciddi yanılgıları veya yetersiz bilgileri olduğunu vurgulamaktadır (Norris \& Phillips 1994; Dagher \& BouJaoude 1997; Dagher, Brickhouse, Shipman \& Letts 2004; Doğanay, Demircioğlu \& Yeşilpınar 2014). Bilimsel bilginin özellikleri ve doğas1 ile ilgili kavram yanılgıları nedeniyle bilimin doğasının doğru algılamasında çok büyük sorunlar yaşanmaktadır.

Sonuç olarak bilimsel süreçlerin öğretimi, bilimsel okuryazarlık açısından öğrencileri yetiştirmek için gerekli olan en önemli faktörler arasında yer almaktadır. Her ne kadar araştırmada öğretmen adayları ve öğretmenlerin sahip oldukları kavram yanılgıları ilgili detaylı bir veri analizi yapılmamış olsa da ortaya çıkan sonuçlar doğrultusunda sınıf öğretmenlerinin ve adaylarının fen konularını anlatırken bu yanılgılarını öğrencilere de aktarmalarının kaçınılmaz olduğu düşünülmektedir. Fen bilimleri ile ilk kez sınıf öğretmenleri vasıtasıyla tanışacak olan öğrencilerin öğretmenleri gibi bu yanılgılara sahip olacakları düşünüldüğünde sınıf öğretmenlerinin bu alanda yetiştirilmeleri ve gerekli farkındalık ve beceri düzeyine sahip olmalarının ne kadar önemli olduğu bir kez daha ortaya çıkmaktadır. 


\section{Öneriler}

Yukarıda tespit edilen sorunların düzeltilmesi için bilim okuryazarı bireylerin eğitilmesine yönelik yeni yaklaşımlara ihtiyaç duyulmaktadır (Abd-El-Khalick \& Lederman 2000). Bilimsel okuryazar bireyler yetiştirmesi beklenen öğretmen adaylarının da ilk başta kendilerinin bu alanda yeterli bilgiye ve donanıma sahip olmalarına ihtiyaç vardır. Türkiye'de ilköğretimde bilimsel okuryazar bireyler yetiştirilmesi Fen Bilimleri Dersi programının vizyonu olarak belirlenmiştir. Bu ders ile ilk defa öğrenciler sınıf öğretmenleri sayesinde karşılaşmakta, bilimin doğası ve bilimsel okuryazarlıkla ilgili kavramlar ilk defa sınıf öğretmenleri tarafindan anlatılmaktadır. Bu nedenle, fen bilgisi öğretmenlerinin yanı sıra öncelikli olarak sınıf öğretmenlerinin ve öğretmen adaylarının bilimsel okuryazarlık alanında bilgi ve beceri birikimleri sağlanmalıdır. Bilimsel okuryazarlık alanındaki bu bilgi ve beceriler ise fen alanı ve fen eğitimi üzerine olan dersler sayesinde kazandırılabilir. Oysaki sınıf öğretmenliği programına yerleşen öğrencilerin büyük bir bölümü liselerin eşit ağırlık alanından mezun olmaları onların fen bilimleri alanındaki ön yeterliliklerini de sınırlamaktadır. Bu sınırlılığın yanı sıra sınıf öğretmenliği için hazırlanan yükseköğretim programı incelendiğinde fen bilimlerine yönelik derslerin birinci sınıfta yoğunlaştığı, fen öğretimine yönelik olanların da üçüncü sınıf dersleri arasında yer aldığ görülmektedir.

Zorunlu dersler dışında fen ve bilimin doğasına yönelik seçmeli derslerin ise programlarında yer almaması, son sınıfta fen bilimlerine ve fen öğretimine yönelik derslerin bulunmaması öğretmen adaylarının bilimin doğasına ilişkin görüşlerinin yetersiz kalmasına yol açtığı düşünülmektedir. Araştırmalar bilimin doğasıyla doğrudan ilişkili derslerin öğretmen adaylarının bilimin doğasına yönelik görüşlerini olumlu etkilediğini göstermektedir (Kapancik 2009; Özbudak 2010). Daha önce de belirtildiği gibi sınıf öğretmenliği programında bilimin doğasına yönelik bir dersin bulunmaması da büyük bir eksiklik olarak görülmektedir.

Yukarıdaki problemlerin aşılabilmesi için sınıf öğretmenlerinin ve öğretmen adaylarının bilimin doğası ile öğrendiklerini sınıf içi uygulamalarında öğrencilere nasıl aktaracaklarına dair deneyimler yaşamaları sağlanmalıdır. Çünkü Macaroğlu, Baysal ve Şahin (1999), öğretmenlerin bilimin doğasına yönelik kazanımlar için hazırladıkları derslerde, yani bilimsel bilginin nasıl üretildiği, hangi koşullarda nasıl geçerli olacağı gibi konuları öğretirken, amaç belirlemekten, dersi işleyiş yolu ve değerlendirme metoduna kadar tüm sınıf etkinliklerinde bilimsel bilginin karakteristik özelliklerine vurgu yapmaları gerektiğini savunmaktadır. Bu nedenle öğretmenlerin öğrencilere eğitim vermeden önce bu becerileri kazanmış olması gerekmektedir (Küçük 2006). Bu içeriğe ve amaca ilişkin hazırlanan dersler ve hizmet içi eğitimler sayesinde sınıf öğretmenleri ve sınıf öğretmenliği adaylarının bilimin doğasına yönelik bilgi ve becerilerinin attırılacağı düşünülmektedir. 


\section{KAYNAKÇA}

Abd-El-Khalick F. \& Boujaoude S. (1997). "An Exploratory Study of Knowledge Base for Science Teaching". Journal of Research in Science Teaching 34/7 (1997) 673-699.

Abd-El-Khalick F. \& Lederman N. G. (2000). "Improving Science Teachers' Conceptions of Nature of Science: A Critical Review of the Literature". International Journal of Science Education 22 (2000) 665-701.

Abd-El-Khalick F. (2001). "Embedding Nature of Science Instruction in Preservice Elementary Science Courses: Abandoning Scientism, But...". Journal of Science Teacher Education 12/3 (2001) 215-233.

Afonso A. S. \& Gilbert J. K. (2010). "Pseudo-Science: A Meaningful Context for Assessing Nature of Science". International Journal of Science Education 32/3 (2010) 329-348.

Aikenhead G., Fleming R. W. \& Ryan A. G. (1989). "CDN 5 form of VOSTS". Kaynak: http://www.usask.ca/education/people/aikenhead/vosts.pdf.

American Association for the Advancement of Science (AAAS). (1990). Science for All Americans. New York 1990.

Aslan O. (2009). Fen ve Teknoloji Öğretmenlerinin Bilimin Doğası Hakkındaki Görüşleri ve Bu Görüşlerin Sinıf Uygulamalarına Yansımaları. Yayımlanmamış Doktora Tezi. Gazi Üniversitesi, Ankara 2009.

Aslan O. (2010). "Fen ve Teknoloji Öğretmenlerinin Bilimsel Bilginin Doğası Hakkındaki Görüşleri”. EJournal of New World Sciences Academy Education Sciences 6/1 (2010) 20-31.

Aslan O., Yalçın N. \& Taşar M. F. (2009). "Fen ve Teknoloji Öğretmenlerinin Bilimin Doğası Hakkındaki Görüşleri”. Ahi Evran Üniversitesi Eğitim Fakültesi Dergisi 10/3 1-8.

Aslan O. \& Tasar M. F. (2013). "How Do Science Teachers View and Teach the Nature of Science? A Classroom Investigation". Education and Science 38/167 (2013) 65-80.

Arı Ü. (2010). Fen Bilgisi Öğretmen Adaylarının ve Sinıf Öğretmen Adaylarının Bilimin Doğası Hakkındaki Görüşlerinin İncelenmesi. Yayımlanmamış Yüksek Lisans Tezi. Fırat Üniversitesi, Elazı̆̆ 2010.

Ayvacı H. Ş. (2007). Bilimin Doğasının Sinıf Öğretmeni Adaylarına Kütle Çekim Konusu İ̧̧erisinde Farklı Yaklaşımlarla Öğretilmesine Yönelik Bir Çalışma. Yayımlanmamış Doktora Tezi. Karadeniz Teknik Üniversitesi, Trabzon 2007.

Ayvacı H. Ş. \& Özbek D. (2015). "Fen Teknoloji Toplum Dersi Kapsamında Yapılan Uygulamaların Fen Bilimleri Öğretmen Adaylarının Bilimin Doğası Algılarına Etkisi”. Hasan Ali Yücel Eğitim Fakültesi Dergisi 12-1(23) (2015)131-152.

Beşli B. (2008). Fen Bilgisi Öğretmen Adaylarının Bilim Tarihinden Kesitler İncelemelerinin Bilimin Doğası Hakkındaki Görüşlerine Etkisi. Yayımlanmamış Yüksek Lisans Tezi. Abant İzzet Baysal Üniversitesi, Bolu 2008.

Buaraphan K. \& Sung-Ong S. (2009). "Thai Pre-Service Science Teachers' Conceptions of the Nature of Science". Asia-Pacific Forum on Science Learning and Teaching 10/1 (2009) 1-22.

Çelik S. (2003). Öğretmen Adaylarının Bilim Anlayışları ve "Fen, Teknoloji ve Toplum" Dersinin Bu Anlayışlara Etkisi. Yayımlanmamış Yüksek Lisans Tezi. Atatürk Üniversitesi, Erzurum 2003.

Çelikdemir M. (2006). Examining Middle School Students' Understanding of the Nature of Science. Unpublished Master Thesis. Middle East Technical University, Ankara 2006.

Çepni S. (2011). Kuramdan Uygulamaya Fen ve Teknoloji Öğretimi. Ankara 2011.

Çetin P. S. (2009). Effect of Conceptual Change Oriented Instruction on Understanding of Gases Concepts. Unpublished Doctoral Thesis. Middle East Technical University, Ankara 2009.

Çınar M. \& Köksal N. (2013). "Sosyal Bilgiler Öğretmen Adaylarının Bilime ve Bilimin Doğasına Yönelik Görüşleri”. Mersin Üniversitesi Eğitim Fakültesi Dergisi 9/2 (2013) 43-57.

Çil E.(2010). Bilimin Doğasının Kavramsal Değişim Pedagojisi ve Doğrudan Yansitıcı Yaklaşım İle Öğretilmesi: Işsı Ünitesi Örneği. Yayınlanmamış Doktora Tezi. Karadeniz Teknik Üniversitesi, Trabzon 2010. 
Dagher Z. R. \& BouJaoude S. (1997). "Scientific Views and Religious Beliefs of College Students: The Case of Biological Evolution". Journal of Research in Science Teaching 34 (1997) 583-590.

Dagher Z. R., Brickhouse N., Shipman H. \& Letts W. (2004). "How Some College Students Represent Their Understanding of Scientific Theories". International Journal of Science Education 26 (2004) 735-755.

Deve F. (2015). Bilim Tarihi Destekli Işık Ünitesinin 7. Sinıf Öğrencilerinin Bilimin Doğası Anlayışlarına Etkisi. Yayımlanmamış Yüksek Lisans Tezi. Recep Tayyip Erdoğan Üniversitesi, Rize 2015.

Doğanay A., Demircioğlu T. \& Yeşilpınar M. (2014). "Öğretmen Adaylarına Yönelik Bilimin Doğası Konulu Disiplinler Arası Öğretim Programı Geliştirmeye İlişkin Bir İhtiyaç Analizi Çalışması”. Turkish Studies - International Periodical for the Languages, Literature and History of Turkish or Turkic 9/5 (2014) 777-798.

Doğan A., Akçay H., Kaya O. \& Öcal E. (2008). “ỉlköğretim Öğrencilerinin Bilim İnsanı Hakkındaki Görüşleri”. VIII. Ulusal Fen Bilimleri ve Matematik Eğitimi Kongresi, Bolu Abant İzzet Baysal Üniversitesi Eğitim Fakültesi (2008).

Doğan N. (2010). "Farklı Liselerde Okuyan 11. Sınıf Öğrencilerinin Bilimin Doğası Hakkındaki Bakış Açılarının Karşılaştıılması”. Gazi Eğitim Fakültesi Dergisi 30/2 (2010) 533-560.

Doğan-Bora N. (2005). Türkiye Genelinde Ortaöğretim Fen Branşı Öğretmen ve Öğrencilerinin Bilimin Doğası Üzerine Görüşlerinin Araştırılması. Yayımlanmamış Doktora Tezi. Gazi Üniversitesi, Ankara 2005.

Doğan-Bora N., Arslan O. \& Çakıroğlu J. (2006). "Lise Öğrencilerinin Bilim ve Bilim İnsanı Hakkındaki Görüşleri”. Hacettepe Üniversitesi Eğitim Fakültesi Dergisi 31 (2006) 32-44.

Doğan N. \& Abd-El-Khalick F. (2008). "Turkish Grade 10 Students' and Science Teachers' Conceptions of Nature of Science: A National Study". Journal of Research in Science Teaching 45/10 1083-1112.

Doğan N., Çakıroğlu J., Çavuş S., Bilican K. \& Arslan O. (2011). "Öğretmenlerin Bilimin Doğası Hakkındaki Görüşlerinin Geliştirilmesi: Hizmetiçi Eğitim Programının Etkisi”. Hacettepe Üniversitesi Ĕ̈itim Fakültesi Dergisi 40 (2011) 127-139.

Erdoğan R. (2004). Investigation of the Preservice Science Teachers' Views on Nature of Science. Unpublished Master Thesis. Middle East Technical University, Ankara 2004.

Eve R. A. \& Dunn D. (1990). "Psychic Powers, Astrology, and Creationism in the Classroom? Evidence of Pseudoscientific Beliefs among High School Biology and Life Science Teachers". The American Biology Teacher 52 (1990) 10-21.

Gess-Newsome J. (2002). "The Use and Impact of Explicit Instruction about the Nature of Science and Science Inquiry in an Elementary Science Methods Course". Science \& Education 11 (2002) 55-67.

Gül M. E. (2014). Doğrudan-Yansıtıcı Yaklaşım Açısından Desenlenen İki Tamamlayıcı Dersin Bilimin Doğasına İlişkin Anlayışlara Etkisi. Yayımlanmamış Yüksek Lisans Tezi. İnönü Üniversitesi, Malatya 2014.

Gürses A., Doğar Ç. \& Yalçın M. (2005). "Bilimin Doğası ve Yükseköğrenim Öğrencilerinin Bilimin Doğasına Dair Düşünceleri”. Milli Eğitim Dergisi 166 (Bahar 2005). Kaynak: http://dhgm.meb.gov.tr/yayimlar/dergiler/Milli_Egitim_Dergisi/166/index3-yalcin.htm

Irez S. (2009). "Nature of Science as Depicted in Turkish Biology Textbooks". Science Education 93 (2009) 422-447.

Kang S., Scharmann L. C. \& Noh T. (2005). "Examining Students' Views on the Nature of Science: Results from Korean $6^{\text {th }}, 8^{\text {th }}$ and $10^{\text {th }}$ Graders". Science Education 89 (2005) 314-334.

Kapancık E. (2009). Kimya Öğretmen Adaylarının Bilimin Doğası Hakkındaki Görüşleri ile İlgili Boylamsal Bir Çalışma. Yayımlanmamış Yüksek Lisans Tezi. Gazi Üniversitesi, Ankara 2009.

Kaya A. (2007). Fen Eğitiminde Bilim Tarihi Destekli Öğretimin Fen Bilgisi Öğretmen Adaylarının Bilim Doğasına İliş̧kin Görüşlerine Etkisinin Değerlendirilmesi. Yayımlanmamış Yüksek Lisans Tezi. Balıkesir Üniversitesi, Balıkesir 2007.

Kenar Z. (2008). Fen Bilgisi Öğretmen Adaylarının Bilimin Doğası Hakkındaki Görüşleri. Yayımlanmamış Yüksek Lisans Tezi. Balıkesir Üniversitesi, Balıkesir 2008. 
Khishfe R. \& Abd-El-Khalick F. (2002). "Influence of Explicit and Reflective Versus Implicit InquiryOriented Instruction on Sixth Graders' Views of Nature of Science". Journal of Research in Science Teaching 39/7 (2002) 551-578.

King B. B. (1991). "Beginning Teachers' Knowledge of and Attitudes Toward History and Philosophy of Science". Science Education 75 (1991)135-141.

Küçük M. (2006). Bilimin Doğasını İlköğretim 7. Sinıf Öğrencilerine Öğretmeye Yönelik Bir Çalışma. Yayımlanmamış Doktora Tezi. Karadeniz Teknik Üniversitesi, Trabzon 2006.

Lederman N. (1999). "Teachers' Understanding of the Nature of Science and Classroom Practice: Factors That Facilitate or Impede the Relationship". Journal of Researching Science Teaching 36 (1999) 916929.

Lederman N. G., Abd-El-Khalick F., Bell R. L. \& Schwartz R. S. (2002). "Views of Nature of Science Questionnaire: Toward Valid and Meaningful Assessment of Learners' Conceptions of Nature of Science". Journal of Research in Science Teaching 39 (2002) 497-521.

Lederman N. G. (1992). "Students' and Teachers' Conceptions of the Nature of Science: A Review of the Research". Journal of Research in Science Teaching 29 (1992) 331-359.

Liu S.Y. \& Lederman N. G. (2007). "Exploring Prospective Teachers' Worldviews and Conceptions of Nature of Science". International Journal of Science Education 29/10 (2007) 1281-1307.

Lucas K. B. \& Roth W-M. (1996). "The Nature of Scientific Knowledge and Student Learning: Two Longitudinal Case Studies". Journal Research in Science Education 26/1 (1996) 103-127.

Macaroğlu E., Baysal N. Z. \& Şahin F. (1999). "İlköğretim Öğretmen Adaylarının Bilimin Doğası Hakkındaki Görüşleri Üzerine Bir Araştırma”. Buca Eğitim Fakültesi Dergisi 10 (1999) 55-62.

McComas W. F. (2003). "A Textbook Case of the Nature of Science: Laws and Theories in the Science of Biology”. International Journal of Science and Mathematics Education 1/2 (2003) 141-155.

MEB (2013). İlköğretim Kurumları Fen Bilimleri Dersi (3, 4, 5, 6, 7 ve 8. Sinıflar) Öğretim Programı. Ankara 2013.

Mıhladız G. (2010). Fen Bilgisi Öğretmen Adaylarının Bilimin Doğası Konusundaki Pedagojik Alan Bilgilerinin Araştırılması. Yayımlanmamış Doktora Tezi. Gazi Üniversitesi, Ankara 2010.

Mıhladız G. \& Doğan A. (2012). "Fen ve Teknoloji Öğretmenleri ve Öğretmen Adaylarının Bilimin Doğası Konusundaki Alan Bilgilerinin Karşılaştırılması". E-International Journal of Educational Research 3/1 (2012) 78-96.

Morgil İ., Temel S., Seyhan H. G. \& Alşan E. U. (2009). "Proje Tabanlı Laboratuvar Uygulamasının Öğretmen Adaylarının Bilimin Doğası Konusundaki Bilgilerine Etkisi”. Türk Fen Eğitimi Dergisi 6/2 (2009) 92-109.

Moss D. M., Abrams E. D. \& Robb J. (2001). "Examining Student Conceptions of the Nature of Science". International Journal of Science Education 23/8 (2001) 771-790.

Murcia K. \& Schibeci R. (1999). "Primary Student Teacher' Conceptions of the Nature of Science". International Journal of Science Education 21/11 (1999) 1123-1140.

National Research Council (NRC). (1996). National Science Education Standards. Washington, DC 1996.

Norris S. \& Phillips L. (1994). "Interpreting Pragmatic Meaning When Reading Popular Reports of Science". Journal of Research in Science Teaching 31 (1994) 947-967.

Özbudak Z. (2010). Fen Bilgisi Öğretmen Adaylarının Bilimin Doğasını Anlama Düzeylerinin Tespit Edilmesi. Yayımlanmamış Yüksek Lisans Tezi. Kocaeli Üniversitesi, Kocaeli 2010.

Özcan H. (2013). Fen Bilgisi Öğretmen Adaylarının Fen İçeriği ile İliş̧kilendirilmiş Bilimin Doğası Konusundaki Pedagojik Alan Bilgilerinin Gelişimi. Yayımlanmamış Doktora Tezi. Gazi Üniversitesi, Ankara 2013.

Palmquist B. \& Finley F. N. (1997). "Preservice Teacher' Views of the Nature of Science during a Post Baccalaureate Science Teaching Program". Journal of Research in Science Teaching 34/6 (1997) 595-615.

Pajares M. F. (1992). "Teacher Beliefs and Educational Research: Cleaning Up a Messy Construct". 
Review of Educational Research 62 (1992) 307-332.

Posnanski T. J. (2010). "Developing Understanding of the Nature of Science Within A Professional Development Program for Inservice Elementary Teachers: Project Nature of Elementary Science Teaching". Journal of Science Teacher Education 21 (2010) 589-621.

Ryan A. G. \& Aikenhead G. S. (1992). "Students' Preconceptions About the Epistemology of Science". Science Education 76 (1992) 559-580.

Sadler T. D., Chambers F. W. \& Dana L. Z. (2004). "Student Conceptualizations of the Nature of Science in Response to a Socio Scientific Issue". International Journal of Science Education 26/4 (2004) 387-409.

Solomon J., Scott L. \& Duveen J. (1996). "Large-Scale Exploration of Pupils' Understanding of the Nature of Science”. Science Education 80/5 (1996) 493-508.

Taber K. S. (2008). "Towards a Curricular Model of the Nature of Science". Science \& Education 17 (2008) 179-218.

Taşar M. F. (2003). "Teaching History and the Nature of Science in Science Teacher Education Programs". Pamukkale Üniversitesi Eğitim Fakültesi Dergisi 1 (2003) 30-42.

Tatar E., Karakuyu Y. \& Tüysüz C. (2011). "Sınıf Öğretmeni Adaylarının Bilimin Doğası Kavramları Hakkındaki Yanlış Anlamaları". Buca Eğitim Fakültesi Dergisi 29 (2011) 153-161.

Water-Adams S. (2006). "The Relationship Between Understanding of the Nature of Science and Practice: The Influence of Teachers Beliefs About Education". International Journal of Science Education 28/8 (2006) 919-944.

Yalçın S. A. \& Yalçın S. (2011). "Analyzing Elementary Teachers' Views on the Nature of Science According to Their Academic Levels". Procedia Social and Behavioral Sciences 15 (2011) 942-946.

Yakmac1 B. (2004). Science (Biology, Chemistry and Physics) Teachers' Views on the Nature of Science as a Dimension of Scientific Literacy. Unpublished Master Thesis. Boğaziçi University, İstanbul 2004.

Zeidler D. L. \& Lederman N. G. (1989). "The Effect of Teachers' Language On Students' Conceptions of the Nature of Science". Journal of Research in Science Teaching 26/9 (1989) 771-783.

Zorlu Y. \& Baykara O. (2015). "Teknoloji Bilimin Uygulaması Mıdır? Fen ve Teknoloji Öğretmen Adaylarının Görüşleri”. Atatürk Üniversitesi Kazım Karabekir Eğitim Fakültesi Dergisi 29 (2015) 123-144. 
